Volume 12, Issue 2, April 2020, 154-167

ISSN 2549-7790 (Online)

ISSN 1979-7192 (Print)

(Bisnis dan Manajemen)

DOI: 10.26740/bisma.v12n2.p154-167

https://journal.unesa.ac.id/index.php/bisma/index

\title{
Analysis and strategy for improving Indonesian coffee competitiveness in the international market
}

\author{
Budi Rahardjo ${ }^{1}$, Bintang Mukhammad Burhanudin Akbar², Yusuf \\ Iskandar $^{3 *}$, and Anita Shalehah ${ }^{4}$ \\ ${ }^{1}$ Faculty of Economics, Universitas Tidar \\ Jl. Kapten Suparman 39 Potrobangsan, Magelang Utara, Jawa Tengah, Indonesia \\ budi.rahardjo@untidar.ac.id \\ ${ }^{2}$ School of Business, Institut Pertanian Bogor \\ Jl. Raya Pajajaran, Bogor, Jawa Barat, Indonesia \\ bintangmba11@gmail.com \\ ${ }^{3}$ Faculty of Business and Humanities, Universitas Nusa Putra \\ Jl. Raya Cibolang No. 21 Sukabumi, Jawa Barat, Indonesia \\ yiskandar.indonesia@gmail.com \\ ${ }^{4}$ Department of Business Administration, Asia University \\ Liufeng Road, Wufeng District, Taichung City, Taiwan \\ 106231070@live.asia.edu.tw
}

\begin{abstract}
In order to face a competitive market environment, knowing the position of the product itself and competitors is needed. Coffee is the main tropical commodity traded in the world. Coffee has great potential and is very competitive. The research objective is to determine the competitiveness of Indonesian coffee and processed coffee beans exports in the international market by using Revealed Comparative Advantage (RCA) to analyze the trade that occurs in several other major exporters such as Brazil, Colombia, and Vietnam as competitors of Indonesian coffee and analyze strategies to increase the competitiveness of Indonesian coffee export in the international market. Indonesia has an average RCA value of 3.64 and is the smallest value compared to other world coffee exporting countries. The small RCA value indicates that Indonesia's comparative advantage still needs to be improved. Based on Export Product Dynamics (EPD), it is known that there are three countries, including Indonesia, which has lost opportunities to be able to trade with other countries, especially coffee products. This condition makes Indonesia needs to improve.
\end{abstract}

\section{To cite this document:}

Rahardjo, B., Akbar, B.M.B., Iskandar, Y., \& Shalehah, A. (2020). Analysis and strategy for improving Indonesian coffee competitiveness in the international market. BISMA (Bisnis dan Manajemen),12(April),154-167. https://doi.org/10.26740/bisma.v12n2.p154-167 
Budi Rahardjo, Bintang Mukhammad Burhanudin Akbar, Yusuf Iskandar, \& Anita Shalehah

Analysis and strategy for improving Indonesian coffee competitiveness in the international market

Production activities and maintain quality. Indonesian coffee products have a variety of types, which, when used, will increase the competitiveness of the Indonesian state.

Keywords: competitiveness; export product dynamics; revealed comparative advantage; strategy.

Received: January 16, 2020; Accepted: February 24, 2020; Published: April 28, 2020

*Corresponding author

Email:yiskandar.indonesia@gmail.com

\begin{abstract}
Abstrak
Dalam rangka menghadapi lingkungan pasar yang kompetitif, mengetahui posisi produk sendiri dan pesaing sangat dibutuhkan. Kopi merupakan komoditas tropis utama yang diperdagangkan di dunia. Kopi memiliki potensi yang besar dan sangat kompetitif. Tujuan penelitian ini adalah mengetahui daya saing ekspor biji kopi dan kopi olahan Indonesia di pasar internasional dengan menggunakan Revealed Comparative Advantage (RCA) untuk menganalisis perdagangan yang terjadi pada beberapa eksportir utama lainnya seperti Brazil, Kolombia dan Vietnam sebagai kompetitor dari kopi Indonesia, dan menganalisis strategi dalam upaya meningkatkan daya saing ekspor kopi Indonesia di pasar internasional. Indonesia memiliki nilai rata-rata RCA sebesar 3.64, dan merupakan nilai terkecil dibandingkan negara-negara pengekspor kopi dunia lainnya. Nilai RCA yang kecil mengindikasikan bahwa keunggulan komparatif yang dimiliki Indonesia masih perlu ditingkatkan. Berdasarkan Export Product Dynamics (EPD) diketahui terdapat tiga negara, termasuk Indonesia yang mengalami kondisi kehilangan peluang untuk mampu melakukan perdangangan dengan negara lain khususnya produk kopi. Kondisi ini menandakan bahwa Indonesia perlu memperbaiki aktivitas produksi dan menjaga kualitas. Pada dasarnya produk kopi Indonesia memiliki jenis yang beragam yang bila dimanfaatkan akan menambah daya saing dari negara Indonesia.
\end{abstract}

Kata kunci: daya saing; export product dynamics; revealed comparative advantage; strategi.

\title{
INTRODUCTION
}

The international market can be interpreted as the interaction of cultivation in the form of exports and imports of goods or services through mutual agreements between countries. International Trade reviewing interdependence between countries that influences the country's political, socio-cultural, and military relations (Sari and Tety, 2017). Trade between countries is currently growing, thus creating a competitive market environment. Facing a competitive market environment knowing the position of one's product and competitors is needed. Identification of one's product position is used as a foundation in formulating the right product marketing strategy to be able to compete in a competitive market environmentincluding agricultural commodities.Agricultural commodities in the development of world trade require increased competitiveness (Firmansyah et al., 2017). 
Coffee is the second largest product traded in the world; coffee has great potential and is very competitive (Zuhdi and Suharno, 2015). According to the Ministry of Agriculture of Indonesia (2016), Indonesia is known worldwide for its specialty as a coffee producer through various coffee and civet coffee variants. The unique taste and aroma of coffee from Indonesia makes Indonesian coffee has an excellent opportunity to be increased in international trade. One of the most developed commodities in the world is commodity coffee (Fadah and Handriyono, 2015). Baroh et al (2014) explain that international trade competition is getting tougher because of the increase of world coffee production unequal with demand for coffee.

Coffee is the main tropical commodity traded in the world, with the contribution of half of the total export of tropical commodities (Rahardjo et al. 2019). Coffee development is inseparable from its role as one of the plantation commodities, which is the focus of development for export purposes. Based on the USDA (2016), Indonesia listed as the fourth largest coffee producer in the world after Brazil, Vietnam, and Colombia. Narulita et al. (2014) stated that Indonesia is the world's fourth-largest coffee commodity exporter, with an average role of 4.76 percent of total world exports. Brazil occupies the first position with an average role of 24.30 percent, followed by Vietnam with 17.94 percent, and Colombia with 10.65 percent. The growth of Indonesian coffee production increased by $2.11 \%$ per year during 1990-2015 and increase in Indonesian coffee productivity of 1.54\% per year (Rosiana et al., 2018).

Coffee is a part of international trade and important agricultural raw material (Torok et al., 2018). Coffee export development is an effort undertakento develop and improve the quality of export crops to maintain existing international market shares and as an effort to make new market penetration following the government's goal to make coffee as one of the primary export commodities Ministry of Agriculture of Indonesia (2016). With the change in international demand for Indonesian coffee products, it is necessary to know the competitiveness of Indonesian coffee by identifying the Indonesian coffee's positioning in international market and how to increase its export. Sachitra and Chong (2016) explained that the making of strategies must be comprehensive, supported by the existence of operational explanations of each predetermined target.

Narulita et al. (2014) argued that in the era of globalization, competition conditions were increasingly fierce, where each country opened its markets to each other. The development of processed coffee products to diversify, such as roasted coffee, instant coffee, coffee mix, decaffeinated coffee, soluble coffee, and ice coffee has a valuable meaning because it is possible to become a superior commodity that has high competitiveness in the international market. Indonesia, as a tropical country, has the opportunity to develop diversified processed coffee products, also has the potential to develop specialties coffee processing industry 
Budi Rahardjo, Bintang Mukhammad Burhanudin Akbar, Yusuf Iskandar, \& Anita Shalehah

Analysis and strategy for improving Indonesian coffee competitiveness in the international market products with distinctive flavors such as; Lintong Coffee, Kintamani Coffee, and Toraja Coffee. Rosiana et al. (2017) explained that increased competitiveness will enhance the market share of a country that is supported by the improvement of the quality, productivity of coffee, and technology.Indonesian coffee production is among the four largest in the world but does not yet have a competitive advantage when compared to other exporting countries (Purnamasari et al., 2014).

This study aims to determine the competitiveness of Indonesian coffee and processed coffee beans exports in the international market by using Revealed Comparative Advantage (RCA), to analyze the trade that occurs in several other major exporters such as Brazil, Colombia, and Vietnam as competitors of Indonesian coffee. This analysis will provide a preliminary interpretation of the position of Indonesian coffee trade in the international market. The second objective is to analyze the strategy to increase the competitiveness of Indonesian coffee exports in the international market. The results will contribute strategies to evaluate the effects of increasingly competitive market pressures and challenges faced by Indonesian coffee in the international market.

\section{Competitive and Comparative Advantage of Indonesian Coffee}

In this study, we analyze the competitiveness of Indonesian coffee. However, there are some differences between competitive and comparative. Comparative advantage is widely believed by us as the main determinant of international production and trade patterns. Porter (1985) emphasized competitiveness at the level of a firm in terms of competitive strategies such as low cost and product differentiation. Porter (1990) said that a nation's competitiveness depends on the capacity of its industry to innovate and upgrade. Companies gain the advantage against the world's best competitors because of pressure and challenge. They benefit from having strong domestic rivals, aggressive home-based suppliers, and demanding local customers. Competitiveness analysis is carried out using a mathematical approach to the measurement of commodity competitiveness in international markets. Quantitative data were processed using the Revealed Comparative Advantage (RCA) analysis to determine the competitiveness of Indonesian coffee in the international market. The RCA method is a method used to measure the comparative advantage of a country's commodities in the international market, which is reflected in the value of its exports.

\section{Export Product Dynamicof Indonesian Coffee}

Export Product Dynamic (EPD) is an analytical method used to identify the competitiveness of a product and to determine the performance of a product, whether dynamic or not, in the flow of export trade in a country. Market position can be known because this method uses total export shares (X) and commodity export shares (Y) as variables (Pradipta and Firdaus, 2014). Although not all products have a high export value, it does not mean that the product has no 
competitiveness.

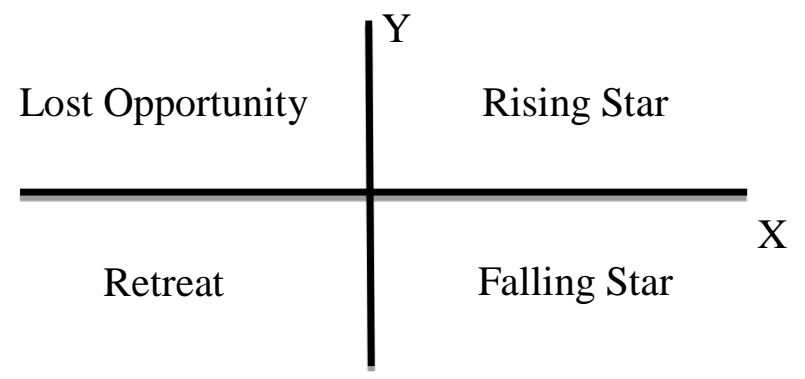

Source: Estherhuizen (2006)

Figure 1. Position the competitiveness of products by the EPD method

Figure 1 explains lost opportunity market share position is a market condition or competitiveness that is least expected by a country because, in this position, there is a decline in market share in domestic products, while the export market share in destination countries has increased. This condition causes a country to lose the opportunity of export coverage for products and goods produced to destination countries and international markets. Conversely, if exports are in a rising star, exports are in the highest market position because in this position exports have increased, and export market share in the international market is increasing. The market position that is not expected by other countries is falling star due to this position, an increase in market share even though it does not occur in products or goods that are dynamic in the global market. A retreat is a condition where a country's product or goods are no longer desirable by market share (Estherhuizen (2006). The competitiveness position matrix with the EPD method can be seen in Table 1.

Table 1. Competitiveness Position Matrix with the EPD Method

\begin{tabular}{ccc}
\hline $\begin{array}{c}\text { Share of Country's Export in } \\
\text { World Trade }\end{array}$ & \multicolumn{2}{c}{$\begin{array}{c}\text { Share of Product in World Trade } \\
\text { Rising (Dynamic) }\end{array}$} \\
& & \\
\hline Rising (Competitive) & Rising Star & Falling Star \\
Falling (Non-competitive) & Lost Opportunity & Retreat \\
\hline
\end{tabular}

Source: Estherhuizen (2006)

\section{METHODS}

The data used in this study are all secondary data with international data coverage. Data obtained from the Central Statistics Agency (bps.go.id 2018), International Trade Center (ITC) (intracen.org 2019), UN Comtrade (comtrade.un.org 2018), and International Coffee Organization (ICO) (ico.org 2019). The data used in the calculation of coffee competitiveness is coffee export data from various countries, including Indonesia, for ten years, from 2009-2018. 
Budi Rahardjo, Bintang Mukhammad Burhanudin Akbar, Yusuf Iskandar, \& Anita Shalehah Analysis and strategy for improving Indonesian coffee competitiveness in the international market

In this analysis, RCA was employed to measure the competitiveness of Indonesian coffee compared to other coffee producers. Several major coffee exporting countries will be calculated so that the comparative advantage can be compared. Mathematically the RCA is formulated in equation (1).

$\mathrm{RCA}=\frac{\mathrm{Xij} / \mathrm{Xit}}{\mathrm{Wj} / \mathrm{Wt}}$

Note:

Xij: export value of commodity $i$ from country $j$

Xit: total export value of the country $j$

$\mathrm{Wj}$ : the value of world commodity exports $\mathrm{i}$

Wt: total world export value

The value of the competitiveness index of a commodity in the RCA has two possibilities, namely: 1) The value of RCA> 1, indicates that the share of commodity $i$ in the total exports of country $j$ is higher than the average share of the commodity concerned in exports of all countries (world). This means that country $\mathrm{j}$ has a comparative advantage (has strong competitiveness) so that it is relatively more specialized in the commodity groups concerned. 2) RCA value $<1$, shows that the share of commodity $i$ in total exports of country $j$ is smaller than the average share of the commodity in question.

To find out the competitiveness of a product as in table 1 can be converted from the quadrant contained in figure 1, where the competitiveness position will be in one of the quadrants. The position in the quadrant represents the business strength (X-axis) and market pull (Y-axis) of a product. Mathematically, the business power or market share (X-axis) of a product is formulated in equation (2), while the market attraction ( $\mathrm{Y}$-axis) is formulated mathematically in equation (3).

$\frac{\sum_{t=1}^{n}\left(\frac{X i}{W i}\right)_{t} \times 100 \%-\sum_{t=1}^{n}\left(\frac{X i}{W i}\right)_{t-1} \times 100 \%}{T}$

Note:

$\mathrm{Xi}$ : The export value of Indonesian products

$\mathrm{Xt}$ : The total value of Indonesian exports

Wi: The export value of the world products

Wt: The total value of world exports

\section{RESULT AND DISCUSSION}


The international market requires players in it to have commodities that have competitiveness to survive in increasingly fierce competition. A country needs to know the level of competitiveness of its commodities that are exhibited in international markets. The measurement of the competitiveness of a commodity serves to determine the strategy in winning the competition in the international market (Firmansyah et al., 2017). This study analyzes the competitiveness of Indonesian coffee in the international market, which aims to provide an initial interpretation of the position of Indonesian coffee trade in the international market and analyze strategies to increase the competitiveness of Indonesian coffee exports in the international market. According to the International Coffee Organization (2019), world coffee consumption from 2014 to 2018 has increased, this is an opportunity for the Indonesian coffee bean export market to get a better market share in the international market. Indonesia must be able to take advantage of this opportunity to improve the export performance of coffee beans to international markets (Alexander and Hendrik, 2019).

The competitiveness of Indonesian coffee in the international market can be seen from its comparative advantage. Based on the Table 2, the competitiveness of Indonesian coffee and other coffee-producing countries, including Brazil, Vietnam, and Colombia, in comparative terms in the international market, was analyzed by the RCA method. RCA measures the export market share of a country in the same industrial group as other exporting countries, so it is widely used to measure comparative advantage (Serin and Civan, 2008). This analysis will compare the RCA value of Indonesian coffee with other major producing countries in the world market. The higher the RCA value, the country has a higher comparative advantage and vice versa. The results of the competitive analysis that has been carried out on the four largest coffee producing and exporting countries in the world, namely Indonesia, Brazil, Vietnam, and Colombia on the international market using the RCA method can be seen in table 2 .

Table 2. Results of Estimated Competitiveness (RCA) of Coffee Export Countries

\begin{tabular}{ccccc}
\hline Year & Brazil & Vietnam & Colombia & Indonesia \\
\hline 2009 & 15.42 & 18.86 & 29.83 & 4.40 \\
2010 & 16.08 & 15.99 & 29.99 & 3.22 \\
2011 & 15.76 & 14.32 & 23.46 & 2.56 \\
2012 & 13.18 & 17.24 & 18.07 & 3.66 \\
2013 & 12.69 & 12.91 & 21.83 & 4.30 \\
2014 & 15.97 & 13.10 & 27.29 & 3.51 \\
2015 & 15.81 & 8.10 & 39.21 & 4.33 \\
2016 & 13.84 & 9.09 & 41.87 & 3.68 \\
2017 & 11.76 & 7.10 & 37.94 & 3.90 \\
2018 & 11.36 & 7.14 & 34.86 & 2.81 \\
RCA average & 14.19 & 12.39 & 30.44 & 3.64
\end{tabular}

Source: International Trade Center (ITC) data processed

Based on Table 2, information is obtained that Indonesia has an average RCA value of 3.64, and is the smallest value compared to other world coffee exporting 
Budi Rahardjo, Bintang Mukhammad Burhanudin Akbar, Yusuf Iskandar, \& Anita Shalehah

Analysis and strategy for improving Indonesian coffee competitiveness in the international market countries. The small RCA value indicates that Indonesian comparative advantage still needs to be improved. Brazil and Vietnam, as the first and second-largest coffee exporting countries, have an average RCA value of 14.19 and 12.39 , respectively. The most considerable average RCA value is owned by the State of Colombia of 30.44 , of which the State of Colombia is the third-largest coffee exporter after Brazil and Vietnam. As the third-largest coffee exporting country in the world, Colombia has a comparative advantage that can be used as a reference to improve the competitive advantage of Indonesian coffee exports.

Indonesia's main competitor as a coffee exporter is Vietnam. This is known from the comparison of RCA values between the two countries over the past ten years, where not even Indonesia has a comparative advantage compared to Vietnam. Vietnam obtained the condition of excellence due to government support through investment in agricultural infrastructure development, research and development, and funding (Zuhdi and Suharno, 2015). Baso and Anindita (2018) explained that government support could encourage an industry in a country to have an advantage over other countries.

Brazil has an average RCA value that is much higher than that of Vietnam. This condition shows that the country of Indonesia is under Brazil. Based on Table 2 above, the high RCA value is known to be caused by the value of total exports, which is far higher than that of Indonesia. This condition indicates that the country of Brazil has an advantage in the amount of production and production quality. Pradipta and Firdaus (2014) explain that the significant value of RCA is caused by high production.

Colombia is a country that has the most considerable RCA value than the other three countries. The high value of RCA from the country of Colombia has led to the superiority of the coffee products produced and the amount of production. Purnamasari et al.,(2014) explained in their research that coffee products from Colombia are dominated by Arabica products, which have higher prices than Robusta coffee products. This condition causes decreased Indonesia's performance, although it remains as a producer with specialty coffee.

Jamil (2019) explained in his research that the low competitiveness of Indonesian coffee is due to the low quality of Indonesian coffee. In line with Jamil (2019) and Narulita et al. (2014), states that the low productivity of smallholder plantations causes the low quality of Indonesian coffee. The low productivity is due to the use of superior seeds, cultivation techniques that are still simple and not supported by the infrastructure yet. Low coffee grade compared to other exporting countries is the reason why Indonesian coffee competitiveness is low (Hidayat \& Soetriono, 2010).

The structure of the coffee business in Indonesia is also one of the causes of the low quality of Indonesian coffee because small-scale farmers produce most of Indonesia's coffee. This condition was stated by Fadah, 2016 which stated that farmers in their research area often harvest coffee before harvest time, the coffee 
beans they harvest are still not ripe and not yet read. Farmer causes the cropping and harvesting patterns carried out by farmersto need money to fulfill their daily needs, including for sudden needs for the education of the farmer's children. Kurniasanti et al. (2014) explains that in a business analysis is needed related to competitiveness and strategies to win competition with other countries. Destrianto (2013) explains that the determination of strategies that have been obtained from the identification of internal and external conditions must refer to the opinions of experts, in order to get a stronger impact.

\section{Analysis of Export Product Dynamic}

The Export Product Dynamicmethod is one of the approaches used to analyze the competitiveness products from several countries (Pradipta and Firdaus, 2014.) During 2009-2018, Colombia had the highest average RCA value of 30.44, while Indonesia had the lowest competitiveness with an average RCA of 3.64. The intense competitiveness of Colombia is supported by the value and volume of exports, which tend to increase every year. The growth in the number of exportable coffee products can be said to continue to increase, especially from 2014 to 2016.

Table 3. Analysis of Export Product Dynamic

\begin{tabular}{|c|c|c|c|c|}
\hline Year & Brazil & Vietnam & Colombia & Indonesia \\
\hline RCA average & 14.19 & 12.39 & 30.44 & 3.64 \\
\hline Export Market Growth & -1.1 & 4 & -3.3 & -2 \\
\hline Product Market Growth & 2.1 & 7.4 & 4.4 & 1 \\
\hline EPD position & $\begin{array}{c}\text { Lost } \\
\text { Opportunity }\end{array}$ & Rising Star & $\begin{array}{c}\text { Lost } \\
\text { Opportunity }\end{array}$ & $\begin{array}{c}\text { Lost } \\
\text { Opportunity }\end{array}$ \\
\hline
\end{tabular}

Source: data processed

Based on Table 3, it is known that there is some big picture which shows that three countries experience the condition of losing the opportunity to be able to trade with other countries, especially coffee products. This position shows that coffee exports in several other countries have a quite good competitor competitiveness in the destination countries. The position of the ideal market share (rising star) is because the country can grow from all sides. According us, countries that experience lost opportunities can be caused by several important factors such as a decline in production in the country, a decline in the country's exchange rate against the dollar and a decline in the quality of production. The strategy to improve the competitiveness of Indonesian coffee export products in the international market, which is in the position of Lost Opportunity, is crucial.

One effort to improve the competitiveness of Indonesian coffee can be made with various technological innovations in aquaculture and processing production in order to increase production and quality. Also, increasing coffee exports in Indonesia can be done through market diversification and product diversification (Sun \& Govind, 2017). Market diversification is done in the interest of looking for 
Budi Rahardjo, Bintang Mukhammad Burhanudin Akbar, Yusuf Iskandar, \& Anita Shalehah

Analysis and strategy for improving Indonesian coffee competitiveness in the international market other destination countries that have export opportunities so they can have the opportunity to dominate the market share to increase the competitive export of Indonesian coffee. Besides, market diversification will The government also needs to open up a broader export market that can accommodate the production of farmers in Indonesia. Meanwhile, product diversification can be done by expanding Indonesian coffee exports not limited to fresh products but in the form of processed products that are expected to increase the added value of Indonesian coffee exports (Sun \& Govind, 2017).

Improvement of domestic transportation facilities needs to be done in order to simplify and shorten the delivery time so that transportation costs will be cheaper and the quality of coffee exports is maintained (TPSA, 2018). The government must open transportation access so that the process of distributing coffee products from farmers to shipping ports will become smoother. Indonesia should increase coffee exports with countries that have high per capita and real incomes because the higher income of a country will tend to increase the country's import capabilities so that it provides an opportunity for Indonesia to increase coffee exports. Improving the image of Indonesian coffee in the world and destination countries can be done through the promotion of coffee through the mass media or coffee festivals both nationally and internationally so that local coffee can be sought after.

Several things need to be done by farmers or coffee industry players at the bottom level. (TPSA, 2018). First, they need to maintain quantity and quality. Second, farmers need to conduct business communication with industry players above and conduct business negotiations. Farmers also need to have official groups or bodies so that the government hears their voices. The government also needs to provide guidance to coffee farmers and listen to their aspirations.

\section{CONCLUSION}

The trade performance of Indonesian coffee products in competitiveness with other countries is the lowest in the RCA value. This condition shows that Indonesia needs to increase production activities and maintain quality. Indonesian coffee products have various types, which, when used, and will increase Indonesia's competitiveness. Low competitiveness is also caused by Indonesia's weakness in maintaining coffee stocks for export and maintaining its quality. Coffee farmers in cooperation with industry players should carry out business communication, especially the coffee products they want and negotiate prices to reach the best agreement.

The EPD analysis shows that Indonesia is in a position of losing opportunities, where it shows that although the coffee market can grow, Indonesia cannot take advantage of this growth. The government of Indonesia could increase their competitiveness through technological innovations in aquaculture and processing production. The government also needs to make a breakthrough in business communication with coffee activists at the lower levels to introduce and 
direct them to adopt new technologies. The Ministry of Trade also needs to diversify markets, especially finding export opportunity with the best benefits for Indonesia. Furthermore, the coffee industry players also need to diversify products, mainly processed coffee and its derivatives. Meanwhile, the government need to improve domestic transportation facilities to improve the investment cenrtainty to global investor. The limitation of study lies on the analysis of export that limited to product dynamics and revealed comparative advantages. Therefore, further research might add gravity model to determine coffee industry's competitiveness.

\section{REFERENCES}

Alexander, I., and Hendrik, J.N. (2019). Competitiveness Analysis Of Export Indonesia Coffee Bean In Global Market 2002-2017. JSEP. 12(2), 116.http://doi.org/10.19184/jsep.v12i2.11271

Central Statistics Agency. (2018). Statistik Kopi Indonesia 2018. Retrieved January 5, 2019, from BPS website: https://www.bps.go.id/publication/2019/12/06/b5e163624c20870bb3d6443 a/statistik-kopi-indonesia-2018.html

Baroh, I., Hanani, N., Setiawan, B., and Koestiono, J. (2014). Indonesian Coffee Competitiveness in the International Market: Armington Model Application.American Journal of Economics. 4(4),184194.http://doi.org/10.5923/j.economics.20140404.03

Baso, R.L., and Anindita, R. (2018). Analysis of competitiveness Indonesia's coffee. Jurnal ekonomi pertanian dan agribisnis. 2(1), 1 9.http://doi.org/10.21776/ub.jepa.2018.002.01.1

Destrianto, P. (2013). Penerapan metode inference tree dan forward chaining dalam sistem pakar diagnosis hama dan penyakit kedelai edamame berdasarkan gejala kerusakannya. Jurnal EECCIS. 7(1), 21-27.Retrieved from https://jurnaleeccis.ub.ac.id/index.php/eeccis/article/view/197

Estherhuizen, D. (2006). An evaluation of the competitiveness of the South African agribusiness sector. Dissertation. Department of Agricultural Economics, Extension and Rural Development - Faculty of Natural and Agricultural Science - University of Pretoria

Fadah, I., and Handriyono. (2015). The Performance Improvement Model of Group and Partnership based Coffee Processing Enterprises in the Jember Regency. Journal of Social and Development Sciences. 6(1), 713.http://doi.org/10.22610 / jsds.v6i1.830.g830

Fadah, I., and Handriyono.(2016). Potential And Problems Of Small And Large Scale Processed Coffee Businesses In Jember Regency. Review of Integrative Business and Economics Research.5(2), 105- 
Budi Rahardjo, Bintang Mukhammad Burhanudin Akbar, Yusuf Iskandar, \& Anita Shalehah Analysis and strategy for improving Indonesian coffee competitiveness in the international market

113.http://repository.unej.ac.id/handle/123456789/89555

Firmansyah, F., Widodo, W., Karsinah, K., \& Oktavilia, S. (2017). Export Performance and Competitiveness of Indonesian Food Commodities. JEJAK: Jurnal Ekonomi Dan Kebijakan. 10(2), 289-301. http://dx.doi.org/10.15294/jejak.v10i2.11294

Hidayat, A., and Soetriono. (2010). Daya Saing Ekspor Kopi Robusta Indonesia Di Pasar Internasional. Journal of Social and Agricultural Economics. 4(2), 62-82.Retrieved from https://jurnal.unej.ac.id/index.php/JSEP/article/view/390

International Coffee Organization. (2019). Historical data on The Global Coffee Trade. Retrieved January 5, 2019, from ICO website: //www.ico.org/ new historical.asp

International Trade Center. (2019). Publication based on countries/territories. Retrieved January 5, 2019, from ITC website: http://www.intracen.org/itc/publications/

Jamil, A.S. (2019). Daya Saing Ekspor Kopi Indonesia di Pasar Global. Agriekonomika, 8(1), 26-35. http://doi.org/10.21107/agriekonomika.v8i1.4924

Kurniasanti, S.A., Sumarwan, U., and Kurniawan, B.P.Y. (2014). Analisis dan model strategi peningkatan daya saing produk edamame beku. Jurnal $\begin{array}{llll}\text { manajemen } \quad \& \quad 11(3), & \text { agribisnis. }\end{array}$ 163. http://doi.org/10.17358/jma.11.3.154-163

Ministry of Agriculture of Indonesia. (2016). Outlook Kopi. Jakarta: Pusat Data dan Sistem Informasi Pertanian Sekretariat Jenderal - Kementerian Pertanian 2016.

Narulita, S., Winandi, R., and Jahroh, S. (2014). Analisis Dayasaing Dan Strategi Pengembangan Agribisnis Kopi Indonesia. Jurnal Agribisnis Indonesia (Journal of Indonesian Agribusiness). 2(1), 63-74. http://doi.org/10.29244/jai.2014.2.1.63-74

Porter, M.E. (1985). Competitive Advantage. Creating and Sustaining Superior Performance. Free Press, New York.

Porter, M.E. (1990). The Competitive Advantage of Nations, Harvard Business Review, March-April.

Pradipta, A., and Firdaus, M. (2014). Posisi daya saing dan faktor-faktor yang memengaruhi ekspor buah-buahan indonesia. Jurnal manajemen dan agribisnis. 11(2), 129-143.http://doi.org/10.17358/jma.11.2.129-143

Purnamasari, M., Hanani, N.,and Huang, W. (2014). Analisis Daya Saing Ekspor Kopi Indonesia Di Pasar Dunia. AGRISE. 14(1), 58-66. 
Rahardjo, B., Rokhani, H., Fahim. M.T. (2019). Coffee Shop Business Model Analysis. Integrated Journal of Business and Economics. 3(2), 140-152. http://doi.org/10.33019/ijbe.v3i2.153

Rosiana, N., Nurmalina, R., Winandi, R., \& Rifin, A. (2017). The Level of Comparative Advantages of World Main Coffee Producers. Buletin Ilmiah Litbang Perdagangan, 11(2), 227-246. http://doi.org/10.30908/bilp.v11i2.274

Rosiana, N., Nurmalina, R., Winandi, R., and Rifin, A. (2018). Dynamics of Indonesian Robusta Coffee Competition Among Major Competitor Countries. Journal of Industrialand Beverage Crops. 5(1), 110.http://dx.doi.org/10.21082/jtidp.v5n1.2018.p1-10

Sachitra, V., and Chong, S.C. (2016). Firm level competitive advantage in the agricultural sector: a research agenda. British journal of economics, management \& trade. $12(3), \quad 1$ 12.http://doi.org/10.9734/BJEMT/2016/24152

Sari, D.R., and Tety, E. (2017). Export Competitiveness Analysis of Coffee Indonesiain The World Market. Jurnal Ilmiah Ekonomi dan Bisnis. 14(1), 105-114. http://doi.org/10.31849/jieb.v14i1.876

Serin, V., and Civan, A. (2008). Revealed Comparative Advantage and Competitiveness: A Case Study for Turkey toward the EU. Journal of Economic and Social Research. 10(2), 25-41.

Sun, W. and Govind, R. (2017). Product market diversification and market emphasis: Impacts on firm idiosyncratic risk in market turbulence. European Journal of Marketing, Vol. 51 No. 7/8, pp. 13081331. http://doi.org/10.1108/EJM-09-2016-0510

The Canada-Indonesia Trade and Private Sector Assistance. (2018). An Analysis of Global Value Chain for Indonesian Coffee Exports. Retrieved April 15, 2020, from http://www.tpsaproject.com/wp-content/uploads/2018-01-30-Report$\underline{1211.03 \mathrm{c} . \mathrm{pdf}}$

Torok, A., Tamas, M., Attila, J. (2018). The Competitiveness of Global Coffee Trade. International Journal of Economics and Financial. 8(5), 16.http://doi.org/10.32479/ijefi.6692

United Nations Comtrade Database. (2018). The International Trade Statistics Yearbook. Retrieved January 5, 2019, from ICO website: https://comtrade.un.org/pb/

United States Department of Agriculture. (2016). Global agricultural information report: Indonesia coffee annual report 2016. Jakarta: FAS USDA.

Zuhdi, F.,and Suharno. (2015). Analisis Daya Saing Ekspor Kopi Indonesia Dan 
Budi Rahardjo, Bintang Mukhammad Burhanudin Akbar, Yusuf Iskandar, \& Anita Shalehah Analysis and strategy for improving Indonesian coffee competitiveness in the international market

Vietnam Di Pasar ASEAN 5. Habitat. 26(3), 152162.http://doi.org/10.21776/ub.habitat.2015.026.3.18 